ORIGINAL ARTICLE

\title{
Immunohistochemical Expression of Gata3 Gene in Patients with Breast Cancer
}

\author{
ZEINAB HEMEED ABBAS ${ }^{1}$, KARRAR S. ZAYED ${ }^{2}$, RIHAB H. ALMUDHAFER ${ }^{3}$, HANAA HEMEED ABBAS ${ }^{4}$ \\ ${ }^{1}$ Faculty of Pharmacy, University of Kufa, Najaf, Iraq; ${ }^{2}$ Faculty of Sciences, University of Kufa, Najaf, Iraq; \\ ${ }^{3}$ Faculty of Medicine, University of Kufa, Najaf, Iraq; ${ }^{4}$ Faculty of Medicine, Jabir Ibn Hayyan Medical University, Najaf, Iraq
}

\begin{abstract}
Breast cancer $(B C)$ is one of the most common cancers in the world. In numerous tissues, including the breast, GATA3 plays an important role in stimulating proliferation and differentiation. The main aims of this study is determining the types of BC (IDC and ILC) then the estimation of the role of GATA3 protein expression by immunohistochemical staining method (IHC) in BC patients and control groups as a biomarker.

The present study was done during the period from October 2020 to April 2021. Sixty seven tissue samples block embedded in wax taken from BC female patients and thirty four of normal non-tumoral breast tissue as a control group collected randomly with their data from three private pathological clinics, these blocks have been prepared between (2014 - 2021), three pathologists re-evaluate each pathologic material.

Regarding to IHC GATA3 protein expression, after histological re-evaluation of slides, the rate of IDC was $80.6 \%$ (54 patients) and of ILC was (19.4\%) (13 patients). The scoring system $+1(37.3 \%)$ and $+2(19.4 \%)$ increased significantly in $\mathrm{BC}$ patients than control $(\mathrm{P}=0.001)$, in addition to, the nuclear positive expression of GATA3 decrease significantly in $\mathrm{BC}$ patients than control (Odd ratio $2.55,95 \% \mathrm{Cl} 1.45-2.37, \mathrm{P}=0.0001$ ), On the other hand, the positivity of GATA3 protein increased significantly in patients with invasive ductal carcinoma (IDC) $(\mathrm{P}=0.001)$.

Keyword: GATA3, Breast Cancer, Immunohistochemical Expression.
\end{abstract}

\section{INTRODUCTION}

$\mathrm{BC}$ is the most frequently diagnosed type of cancer in women and the second greatest cause of cancer death (Nam et al., 2010) until 2020, BC became the first greteat reason of death in 2020 (WHO fact sheet, 2021). It has the greatest reason of death rate caused by carcinoma (15\%), behind lung carcinoma (Baade, 2017), accounting for 458 000 fatalities annually (Altobelli, 2017). BC is a heterogeneous collection of diseases and not a single disease. It can be classified into at least 4 molecular subtypes which included from luminal $A$, luminal $B$, basallike, and HER2-enriched (Pandit et al. 2020).

Approximately $70 \%$ of BC are positive estrogen receptor (ER)/ positive progesterone receptor (PR) are responded to hormonal therapy whereas the rest $30 \%$ of $\mathrm{BC}$ was no responding for hormonal therapy. Additional markers can be used to enhance the predictive response of hormone might significantly progress the management proposal for a large number of BC patients (Purvi et al., 2005).

GATA3, also known as a Trans-Acting T-cell-Specific Transcription Factor, is a zinc finger transcription element that governs the differentiation and morphogenesis of a kinds of tissues, involving the breast (Cakir et al., 2017). It has been demonstrated that requirement of GATA3 is essential for the development of luminal cells in mammary glands (Fu et al., 2020).

The expression of the GATA3 protein is associated with hormone responsiveness and ER expression, showing that it plays a role in the carcinogenesis of ER-positive BC (Hruschka et al., 2020). A high level of GATA3 expression is related to a low grade of tumor and a sluggish ratio of proliferation. The highest amount of GATA3 expression is observed in tumors classified as 'luminal A,' which is the subtype related to the best survival consequence. Therefore, the level of GATA3 expression may be predictive of patient outcome, implying that it may be useful as a prognostic indicator in BC (Perou et al., 2000; Demir et al., 2010). This is to be anticipated, considering that ERpositive breast tumors are typically well-differentiated morphologically and have a favorable prognosis( Shaoxian et al., 2016). About 96 percent of ER -positive breast tumors showed GATA3, whereas only $22 \%$ of ER -negative tumors do.

Aim of the study: is studying the expression of GATA3 gene in patients with breast cancer by estimation of GATA3 protein expression in $\mathrm{BC}$ patients and control groups by the IHC.

Collection of Samples: This retrospective study was accomplished in Middle Euphrates Unit for Cancer Research, Faculty of Medicine, University of Kufa, during the period from October 2020 to April 2021.Immunohistochemistry study were completed in Middle Euphrates Unit for Cancer Research, Faculty of Medicine, University of Kufa. It is carried out on sixty-seven cases of $B C$ in the form of an available Paraffin blocks who underwent surgical resection between 2015 and 2020, these data collected from the archives of three private laboratories. Three pathologists histologically re-evaluated each pathologic material, Patients clinicopathological characteristics are obtained from electronic medical records of these laboratories. GATA3 expression is achieved by IHC. In addition, thirty-four blocks of normal non-tumor breast tissue are collected randomly during the collection of breast cancer.

Histopathological Examination: Five $\mu \mathrm{m}$-thick layers are cut from paraffin embeded tissues. These sections stained by using routine stain method called Haematoxylin and Eosin method (Falkeholm et al.,2001).

Statistical analysis: Data have been analysed by using SPSS version 21 and Pad Graphprism version 7, nominal variables were expressed as number and percent. Student t-test was used to compare mean between two groups, 
when variables were normally distributed. Chi-square test was used to compare frequencies. P-value was regarded as significant when it was less than or equal to 0.05 .

\section{RESULTS:}

The patients group was subdivided histologically into two subgroups; Invasive Ductal Carcinoma (IDC) and Invasive Lobular Carcinoma (ILC). Majority of cases 54 cases $(80.6 \%)$ were of IDC subtype whereas ILC subtype cases were seen in $13(19.4 \%)$ cases, as seen in (Figure 1).Nuclear IHC positive expression of GATA3 was decreased significantly in patients group 42 patients $(62.7 \%)$ in comparison for control group 34 persons (100\%) while the negative expression of GATA3 was decreased significantly in patients group (25 patients) (37.3\%) as compared with control group 0 persons $(0.0 \%)(\mathrm{P}=0.0001)$. On the other hand, Odd ratio for this protein was $2.5595 \%$ $\mathrm{Cl}(1.45-2.37)$ as shown in (Table 1) and (Figures 1,2, and 3).

\begin{tabular}{|c|c|c|c|c|c|}
\hline \multirow{2}{*}{$\begin{array}{l}\text { Nuclear IHC of } \\
\text { GATA3 expression }\end{array}$} & \multicolumn{2}{|c|}{ Control Group } & \multicolumn{2}{|c|}{ Patients Group } & \multirow{2}{*}{$\begin{array}{l}\text { Odd } \\
\text { ratio } \\
(95 \% \\
\text { Cl) }\end{array}$} \\
\hline & No. & $\%$ & No. & $\%$ & \\
\hline Positive expression & 34 & 100.00 & 42 & 62.7 & \multirow{3}{*}{$\begin{array}{l}2.55 \\
-1.45) \\
(2.37\end{array}$} \\
\hline $\begin{array}{l}\text { Negative } \\
\text { expression }\end{array}$ & 0 & $\% 0.0$ & 25 & 37.3 & \\
\hline Total & 34 & 100.00 & 67 & $\begin{array}{l}100.0 \\
0\end{array}$ & \\
\hline
\end{tabular}

Table 1: GATA3 nuclear expression in two groups of the study.

$\mathrm{P}=0.0001$

$\mathrm{Cl}=$ Confidence interval

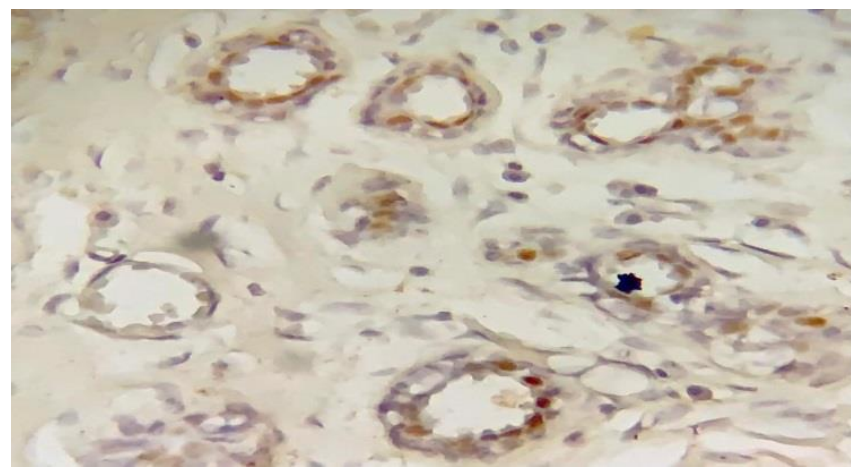

Figure 1: Normal breast acini tissue positive for GATA3 IHC 400X.

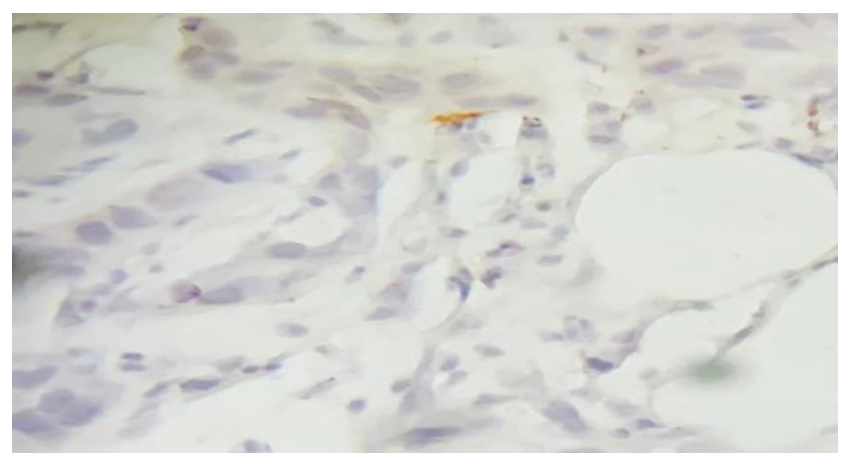

Figure 2: Invasive lobular carcinoma negative for GATA3 $\mathrm{IHC} 400 \mathrm{X}$.

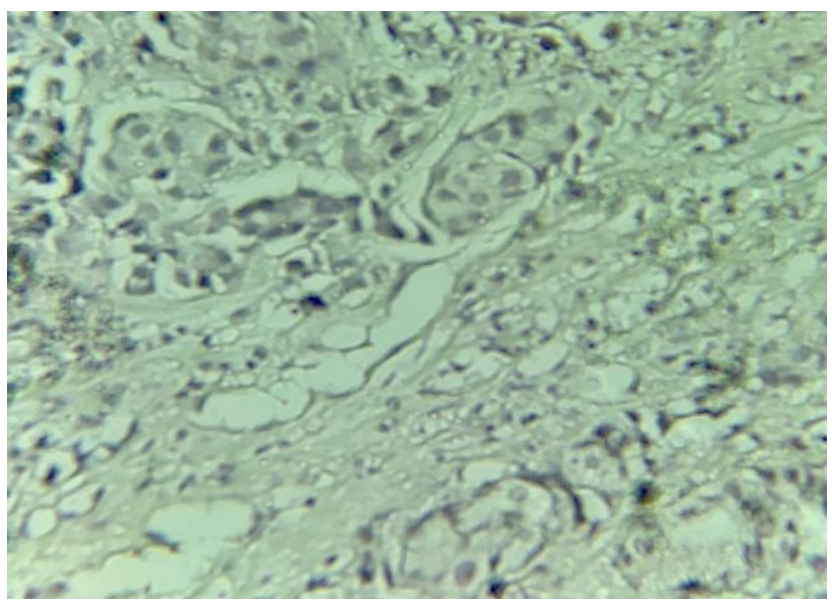

Figure 3: Moderately differentiated invasive ductal carcinoma of breast negative for GATA3 IHC $\times 400$.

GATA3 protein expression was increased significantly in patients group more than in control group $(P=0.001)$. Twenty-five patients $(19.4 \%)$ have score +1 expression, ten patients $(14.9 \%)$ have score +2 patients, eleven patients $(16.4 \%)$ have score +3 expression and eight patients $(11.9 \%)$ have score +4 expression. All control subjects were positive for GATA3 expression, fourteen patients $(41.2 \%)$ and fourteen patients $(41.2 \%)$ were +3 and +4 respectively as seen in (Table 2 ) and (Figure 4 ).

\begin{tabular}{|l|l|l|l|l|l|l|}
\hline \multirow{2}{*}{ Scoring } & \multicolumn{2}{|l|}{ Control } & \multicolumn{2}{l|}{ Patients } & \multicolumn{2}{l|}{ Total } \\
\cline { 2 - 7 } & No. & $\%$ & No. & \% & No. & \% \\
\hline $\mathbf{0}$ & 0 & $\% 0.0$ & 25 & $\% 37.3$ & 25 & $\% 24.8$ \\
\hline $\mathbf{1 +}$ & 0 & $\% 0.0$ & 13 & $\% 19.4$ & 13 & $\% 12.9$ \\
\hline $\mathbf{2 +}$ & 6 & $\% 17.6$ & 10 & $\% 14.9$ & 16 & $\% 15.8$ \\
\hline $\mathbf{3 +}$ & 14 & $\% 41.2$ & 11 & $\% 16.4$ & 25 & $\% 24.8$ \\
\hline $\mathbf{4 +}$ & 14 & $\% 41.2$ & 8 & $\% 11.9$ & 22 & $\% 21.8$ \\
\hline
\end{tabular}

Table 2: GATA3 protein expression in BC in two groups scoring.

$\mathrm{P}=0.001$

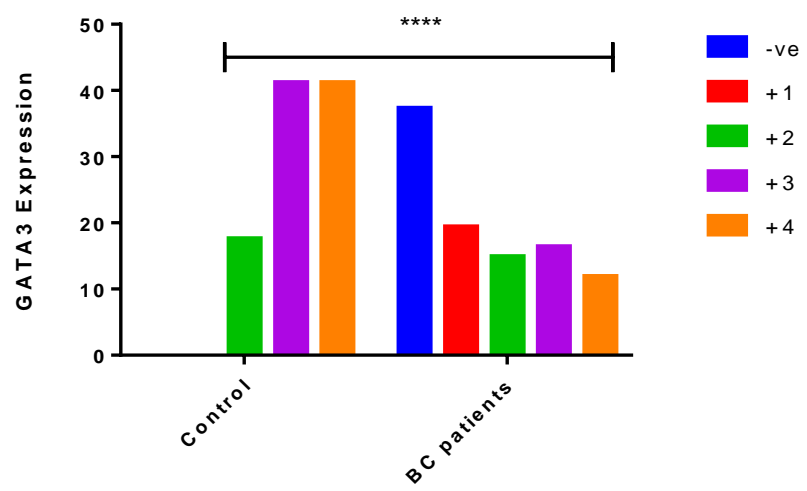

Figure 4: GATA3 protein expression in BC in two groups scoring.

$$
* * * *=(P=0.001)
$$

Nuclear positive expression of GATA3 was increased significantly in patients with (IDC) 39 patients $(72.2 \%)$ when compared with (ILC) patients individuals $(32.1 \% \%)$ $(P=0.001)$ as seen in (Table 3$)$ and (Figure 5). 
Table 3: BC Histological Types and GATA3 protein expression.

\begin{tabular}{|l|l|l|l|l|l|l|}
\hline \multirow{2}{*}{$\begin{array}{l}\text { Histological Type } \\
\text { of BC }\end{array}$} & \multicolumn{2}{|l|}{$\begin{array}{l}\text { Negative } \\
\text { expression }\end{array}$} & \multicolumn{2}{l|}{$\begin{array}{l}\text { Positive } \\
\text { expression }\end{array}$} & \multicolumn{2}{|l|}{ Total } \\
\cline { 2 - 7 } & No. & $\%$ & No. & $\%$ & No. & $\%$ \\
\hline $\begin{array}{l}\text { Invasive ductal } \\
\text { carcinoma }\end{array}$ & 15 & $\% 27.8$ & 39 & $\% 72.2$ & 54 & $\begin{array}{l}100 \\
\%\end{array}$ \\
\hline $\begin{array}{l}\text { Invasive lobular } \\
\text { carcinoma }\end{array}$ & 10 & $\% 76.9$ & 3 & $\% 32.1$ & 13 & $\begin{array}{l}100 \\
\%\end{array}$ \\
\hline
\end{tabular}

$\mathrm{P}=0.001$, Pearson Chi-Square Test

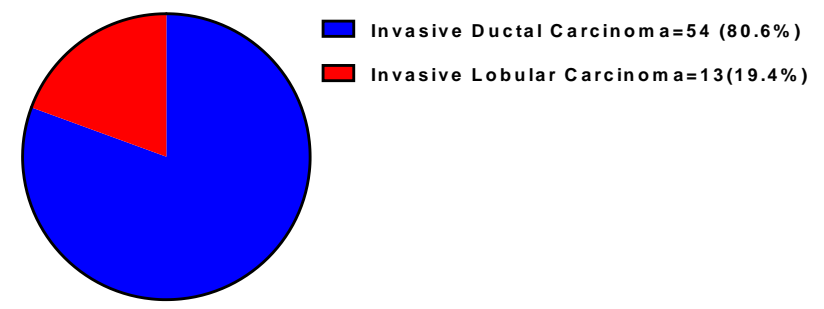

Figure 5: Histological subtypes of BC.

\section{DISCUSSION:}

This study discovered that positive expression of GATA3 protein decreased significantly in the tissues of BC patients compared to controls with normal tissue that contains no negative GATA3 expression, whereas 37.3 percent of BC patients enrolled in this study have negative GATA3 expression. In agree with the current outcomes, preceding study has proven that the GATA3 expression level in patients of $\mathrm{BC}$ is reduced in comparison with normal tissue of breast in control group (Hisamatsu et al., 2015; Thakkar et al., 2015; Guo et al., 2017; Yang et al., 2017; AbdElghany et al., 2019). Luminal subtypes are the most prevalent type of breast cancer and exhibit the greatest levels of GATA3 expression (Mehra et al., 2005; Voduc et al., 2008). GATA3 levels have been demonstrated to alter the ability of luminal stem/progenitor cells to initiate tumors but not basal stem/progenitor cells, showing a GATA3 vital action for in adjusting the distinction of the cells of luminal progenitor in normal state or malignant tissue of $B C$ (Asselin-Labat et al., 2011). GATA3 is frequently coexpressed with its exact aim, the receptor of estrogen (ER), and functions in a positive feedback circle (Albergaria et al., 2009; Ciocca et al., 2009).

GATA3 is a much characterized reason in the formation of glandular cells of breast. GATA3 is required for development of mammary during embryonic life and is implicated in the maintenance of the differentiated condition of the mammary gland's luminal epithelial cells in adults (Yoon et al., 2010; Tokuda et al., 2012). Not amazingly, expression of GATA3 loss has been implicated in the pathophysiology of $\mathrm{BC}$, with lesser expression degrees being associated with receptors of progesterone and estrogen (ER and PR) negative, overexpression of Her2/neu, and bad prognosis (Ademuyiwa et al., 2010; Naoi et al., 2011; Oshima et al., 2011). Overexpression of GATA3 is believed to cause the abnormal production of aromatase in BC (Brychtova et al., 2011).

Previously, we observed that GATA3 expression is dramatically enhanced in cases of $\mathrm{BC}$ as compared with normal epithelium of breast using expression of gene array analysis and real-time quantitative reverse transcriptase PCR (Ren et al., 2004).

GATA3 is required for appropriate development of mammary gland. GATA3 is demonstrated to stimulate luminal cell development when it was introduced into a pure mammary progenitor-enriched people (Asselin-Labat et al., 2007). GATA3 is existing in cells of the luminal epithelium of human breast tissue as well as is also expressed in BC ( Kouros-Meh et al., 2004). In BC, GATA3 expression is intensely correlated with forkhead box $A 1$ (FOXA1) expression and estrogen receptor (ER) (KourosMehr et al., 2008). FOXA1 is required for the transcriptional function of ER (Bernardo et al, 2010). Additionally, it has been reported that GATA3 may act as a mucin1(MUC1) transcriptional upregulation mediator in BC. These findings strongly suggest the requirement of GATA3 for the formation and discrimination of cells of luminal epithelium, which is logical with GATA3 being expressed preferentially in luminal-type breast cancer (Demir et al., 2010).

\section{CONCLUSION:}

These findings suggest that GATA3 is involved in epithelial cell growth control and differentiation maintenance, and that GATA3 may play a role in carcinogenesis in ERpositive BC. GATA3 as a more reliable and sensitive diagnostic marker for ductal $\mathrm{BC}$ and as distinguishable marker for molecular subtypes of BC.

\section{REFERENCES:}

1. Abd-Elghany, M. I., AMohamed, F. E. Z., Toni, N. D., \& Boshra, M. S. (2019). GATA-binding protein 3 and androgen receptor expressions in invasive breast cancer: the relationship with molecular phenotypes, disease progression, and survival outcomes. Egyptian Journal of Pathology, 39(1), 212.

2. Ademuyiwa, F. O., Thorat, M. A., Jain, R. K., Nakshatri, H., \& Badve, S. (2010). Expression of Forkhead-box protein A1, a marker of luminal $A$ type breast cancer, parallels low Oncotype DX 21-gene recurrence scores. Modern Pathology, 23(2), 270-275.

3. Albergaria, A., Paredes, J., Sousa, B., Milanezi, F., Carneiro, V., Bastos, J., ... \& Schmitt, F. (2009). Expression of FOXA1 and GATA-3 in breast cancer: the prognostic significance in hormone receptor-negative tumours. Breast cancer research, 11(3), 1-15.

4. Altobelli, E., Rapacchietta, L., Angeletti, P. M., Barbante, L., Profeta, F. V., \& Fagnano, R. (2017). Breast cancer screening programmes across the WHO European region: differences among countries based on national income level. International journal of environmental research and public health, 14(4), 452

5. Asselin-Labat, M. L., Sutherland, K. D., Barker, H., Thomas, R., Shackleton, M., Forrest, N. C., ... \& Visvader, J. E. (2007). Gata-3 is an essential regulator of mammary-gland morphogenesis and luminal-cell differentiation. Nature cell biology, 9(2), 201-209.

6. Asselin-Labat, M. L., Sutherland, K. D., Vaillant, F., Gyorki, D. E., Wu, D., Holroyd, S., ... \& Visvader, J. E. (2011). Gata3 negatively regulates the tumor-initiating capacity of mammary luminal progenitor cells and targets the putative tumor suppressor caspase-14. Molecular and cellular biology, 31(22), 4609-4622.

7. Baade, P. (2017). Geographical variation in breast cancer outcomes.

8. Bernardo, G. M., Lozada, K. L., Miedler, J. D., Harburg, G., Hewitt, S. C., Mosley, J. D., ... \& Keri, R. A. (2010). FOXA1 
is an essential determinant of ERa expression and mammary ductal morphogenesis. Development, 137(12), 2045-2054.

9. Brychtova, V., Vojtesek, B., \& Hrstka, R. (2011). Anterior gradient 2: a novel player in tumor cell biology. Cancer letters, 304(1), 1-7.

10. Cakir, A., Gonul, I. I., Ekinci, O., Cetin, B., Benekli, M., \& Uluoglu, O. (2017). GATA3 expression and its relationship with clinicopathological parameters in invasive breast carcinomas. Pathology-Research and Practice, 213(3), 227234.

11. Ciocca, V., Daskalakis, C., Ciocca, R. M., Ruiz-Orrico, A., \& Palazzo, J. P. (2009). The significance of GATA3 expression in breast cancer: a 10-year follow-up study. Human pathology, 40(4), 489-495.

12. Demir, H., Turna, H., Can, G., \& Ilvan, S. (2010). Clinicopathologic and prognostic evaluation of invasive breast carcinoma molecular subtypes and GATA3 expression. Journal of BU ON.: official journal of the Balkan Union of Oncology, 15(4), 774-782.

13. Falkeholm, L., Grant, C. A., Magnusson, A., \& Möller, E. (2001). Xylene-free method for histological preparation: a multicentre evaluation. Laboratory investigation, 81(9), 12131221.

14. Fu, N. Y., Nolan, E., Lindeman, G. J., \& Visvader, J. E. (2020). Stem cells and the differentiation hierarchy in mammary gland development. Physiological reviews, 100(2), 489-523.

15. Guo, Y., Yu, P., Liu, Z., Maimaiti, Y., Chen, C., Zhang, Y., ... \& Huang, T. (2017). Prognostic and clinicopathological value of GATA binding protein 3 in breast cancer: A systematic review and meta-analysis. PloS one, 12(4), e0174843.

16. Hisamatsu, Y., Tokunaga, E., Yamashita, N., Akiyoshi, S., Okada, S., Nakashima, Y., ... \& Maehara, Y. (2015). Impact of GATA-3 and FOXA1 expression in patients with hormone receptor-positive/HER2-negative breast cancer. Breast cancer, 22(5), 520-528.

17. Hruschka, N., Kalisz, M., Subijana, M., Graña-Castro, O., Del Cano-Ochoa, F., Brunet, L. P., ... \& Martinelli, P. (2020). The GATA3 X308_Splice breast cancer mutation is a hormone context-dependent oncogenic driver. Oncogene, 39(32), 5455-5467.

18. Kouros-Mehr, H., Bechis, S. K., Slorach, E. M., Littlepage, L. E., Egeblad, M., Ewald, A. J., ... \& Werb, Z. (2008). GATA-3 links tumor differentiation and dissemination in a luminal breast cancer model. Cancer cell, 13(2), 141-152.

19. Kouros-Mehr, H., Slorach, E. M., Sternlicht, M. D., \& Werb, Z. (2006). GATA-3 maintains the differentiation of the luminal cell fate in the mammary gland. Cell, 127(5), 1041-1055.

20. Mehra, R., Varambally, S., Ding, L., Shen, R., Sabel, M. S., Ghosh, D., ... \& Kleer, C. G. (2005). Identification of GATA3 as a breast cancer prognostic marker by global gene expression meta-analysis. Cancer research, 65(24), 1125911264.

21. Nam, J. M., Onodera, Y., Bissell, M. J., \& Park, C. C. (2010). Breast cancer cells in three-dimensional culture display an enhanced radioresponse after coordinate targeting of integrin $\alpha 5 \beta 1$ and fibronectin. Cancer research, 70(13), 5238-5248.

22. Naoi, Y., Kishi, K., Tanei, T., Tsunashima, R., Tominaga, N., Baba, Y., ... \& Noguchi, S. (2011). Prediction of pathologic complete response to sequential paclitaxel and 5fluorouracil/epirubicin/cyclophosphamide therapy using a 70gene classifier for breast cancers. Cancer, 117(16), 36823690 .

23. Oshima, K., Naoi, Y., Kishi, K., Nakamura, Y., Iwamoto, T., Shimazu, K., ... \& Noguchi, S. (2011). Gene expression signature of TP53 but not its mutation status predicts response to sequential paclitaxel and 5FU/epirubicin/cyclophosphamide in human breast cancer. Cancer letters, 307(2), 149-157.

24. Pandit, P., Patil, R., Palwe, V., Gandhe, S., Patil, R., \& Nagarkar, R. (2020). Prevalence of molecular subtypes of breast cancer: a single institutional experience of 2062 patients. European journal of breast health, 16(1), 39.

25. Perou, C. M., Sørlie, T., Eisen, M. B., Van De Rijn, M., Jeffrey, S. S., Rees, C. A., ... \& Botstein, D. (2000). Molecular portraits of human breast tumours. nature, 406(6797), 747-752.

26. Ren, J., Agata, N., Chen, D., Li, Y., Yu, W. H., Huang, L., ... \& Kufe, D. (2004). Human MUC1 carcinoma-associated protein confers resistance to genotoxic anticancer agents. Cancer cell, 5(2), 163-175.

27. Shaoxian, T., Baohua, Y., Xiaoli, X., Yufan, C., Xiaoyu, T., Hongfen, L., ... \& Wentao, Y. (2017). Characterisation of GATA3 expression in invasive breast cancer: differences in histological subtypes and immunohistochemically defined molecular subtypes. Journal of Clinical Pathology, 70(11), 926-934.

28. Thakkar, A., Raj, H., Ravishankar, Muthuvelan, B., Balakrishnan, A., \& Padigaru, M. (2015). High expression of three-gene signature improves prediction of relapse-free survival in estrogen receptor-positive and node-positive breast tumors. Biomarker insights, 10, BMI-S30559.

29. Tokuda, E., Seino, Y., Arakawa, A., Saito, M., Kasumi, F., Hayashi, S. I., \& Yamaguchi, Y. (2012). Estrogen receptor-a directly regulates sensitivity to paclitaxel in neoadjuvant chemotherapy for breast cancer. Breast cancer research and treatment, 133(2), 427-436.

30. Voduc, D., Cheang, M., \& Nielsen, T. (2008). GATA-3 expression in breast cancer has a strong association with estrogen receptor but lacks independent prognostic value. Cancer Epidemiology and Prevention Biomarkers, 17(2), 365-373.

31. Yang, Y., Lu, S., Zeng, W., Xie, S., \& Xiao, S. (2017). GATA3 expression in clinically useful groups of breast carcinoma: a comparison with GCDFP15 and mammaglobin for identifying paired primary and metastatic tumors. Annals of diagnostic pathology, 26, 1-5.

32. Yoon, N. K., Maresh, E. L., Shen, D., Elshimali, Y., Apple, S., Horvath, S., ... \& Goodglick, L. (2010). Higher levels of GATA3 predict better survival in women with breast cancer. Human pathology, 41(12), 1794-1801. 